\title{
Motivasi Belajar Mahasiswa pada Pembelajaran Daring Selama Pandemik Covid-19
}

\section{Md. Aditya Dharma1*, Md. Padmarani Sudewiputri2}

1,2 Universitas Triatma Mulya, Jembrana, Indonesia

\section{ARTICLE INFO \\ Article history: \\ Received June 22, 2021 \\ Revised June 30, 2021 \\ Accepted July 14, 2021 \\ Available online July 25, 2021 \\ Kata Kunci: \\ Motivasi, Pembelajaran Daring, \\ Pandemik Covid-19 \\ Keywords: \\ Motivation, Online Learning, \\ Covid-19 Pandemic

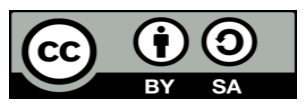 \\ This is an open access article under the CC BY-SA license. \\ Copyright (ㄷ) 2021 by Author. \\ Published by Universitas Pendidikan Ganesha.}

\begin{abstract}
A B S T R A K
Penelitian ini bertujuan untuk menjelaskan secara detail bagaimana kondisi objektif motivasi yang dialami mahasiswa dalam pembelajaran daring pada masa pandemic Covid-19. Penelitian ini menggunakan pendekatan kuantitatif dengan metode survey. Penelitian dilakukan dengan melibatkan 50 mahasiswa aktif. Teknik pengumpulan data pada penelitian ini menggunakan teknik survey dengan skala likert. Survey dibuat dalam google form agar mudah diakses oleh mahasiswa. Adapun teknik analisis data yang digunakan dalam penelitian ini adalah menghitung presentase data dari setiap indikator, kemudian menginterpretasi skor presentasi data dan menganalisis setiap indikatornya secara mendalam. Hasil penelitian ini menunjukkan bahwa motivasi belajar mahasiswa pada pembelajaran daring selama pandemic covid 19 masuk dalam kategori baik, hal itu didapatkan dari skor presentase motivasi tersebut yang berjumlah 76,33\%. Kesimpulan dalam penelitian ini adalah dari 8 indikator motivasi belajar yaitu konsentrasi, rasa ingin tahu, semangat, kemandirian, kesiapan, antusias atau dorongan, pantang menyerah, dan percaya diri menunjukkan kriteria baik, hal ini dapat dikatakan bahwa ditengah pandemic covid-19 yang melanda dunia, hal tersebut tidak menjadi alasan mahasiswa untuk memiliki motivasi belajar yang tinggi, walaupun dalam pelaksanaannya terdapat kekurang-kekurangan yang ditemukan, akan tetapi tidak ada pilihan lain selain mengoptimalkan pembelajaran daring, karena dalam kondisi darurat seperti ini, hanya teknologilah yang menjadi jembatan dalam mentransfer pengetahuan dari dosen ke mahasiswa.
\end{abstract}

\begin{abstract}
A B S TRA C T
This research aims to explain in detail how the objective conditions of motivation experienced by students in online learning during the Covid-19 pandemic. This research uses a quantitative approach with survey methods. The study involved 50 active students. The data collection technique in this study uses survey techniques with likert scale. Surveys are created in google forms to be easily accessible to students. The data analysis technique used in this study is to calculate the percentage of data from each indicator, then interpret the data presentation score and analyze each indicator in depth. The results of this study showed that student learning motivation in online learning during the covid 19 pandemic falls into the good category, it is obtained from the percentage of motivation scores amounting to $76.33 \%$. The conclusion in this study is from 8 indicators of learning motivation, namely concentration, curiosity, spirit, independence, readiness, enthusiasm or encouragement, unyielding, and confident showing good criteria, it can be said that in the midst of the covid-19 pandemic that hit the world, it is not a reason for students to have high learning motivation, although in its implementation there are shortcomings found, But there is no other choice but to optimize online learning, because in an emergency like this, only technology is the bridge in transferring knowledge from lecturers to students.
\end{abstract}

\section{PENDAHULUAN}

Revolusi Industri 4.0 pertama kali muncul tahun 2011 di Jerman sebagai proposal untuk pengembangan konsep kebijakan ekonomi (Fitriyani et al., 2020) strategi dalam menerapkan revolusi industri tersebut menggunakan teknologi informasi tingkat tinggi (Yin \& Qin, 2019), kebijakan tersebut telah mengalami perubahan yang bersifat eksponensial yang ditandai dengan munculnya robotika, drone, sensor, pencetakan 3D, internet of things (IoT), artificial intelegences, big data, dan lainnya (Tinmaz \& Lee, 2019). Era Revolusi Industri 4.0 mengakibatkan semakin eratnya batas antara manusia, mesin indrustri, teknologi informasi dan komunikasi yang berdampak pada seluruh aspek kehidupan (Fomunyam, 2019). Perkembangan teknologi di era revolusi industri 4.0 telah merubah pola kehidupan masyarakat, setiap individu harus mengikuti perkembangan teknologi dan tahu bagaimana memanfaatkannya sehingga membuat hidup setiap orang menjadi lebih mudah (Sarıçoban et al., 2019).

Perkembangan teknologi menjadi sebuah potensi dalam berbagai bidang khususnya dalam bidang pendidikan sehingga harus direspon secara positif dan adaptif dalam menjawab tantangan abad 21 
yang penuh kompleksitas (Aziz Hussin, 2018; Gamar et al., 2018). Penggunaan teknologi dalam dunia pendidikan telah menjadi isu yang sagat penting dan sering dibicarakan dalam berbagai kegiatan (Orgaz et al., 2018; Traxler, 2018), keberadaan teknologi bagi dunia pendidikan merupakan sarana yang dapat dipakai sebagai media penyampaian program pembelajaran baik secara searah maupun secara interaktif (Husaini, 2019), (proses belajar tidak lagi dibatasi oleh ruang kelas tertentu (Erwinsyah, 2017), selain itu penggunaan teknologi telah memungkinkan munculnya pembelajaran jarak jauh dan mendorong inovasi yang lebih besar dalam menciptakan metode pengajaran di dalam dan di luar kelas (Almeida \& Simoes, 2019).

Pembelajaran daring merupakan sebuah inovasi pendidikan yang melibatkan unsur teknologi informasi dalam pembelajaran. Pembelajaran daring merupakan Mustofa et al., (2019) sistem pendidikan jarak jauh dengan sekumpulan metoda pengajaran dimana terdapat aktivitas pengajaran yang dilaksanakan secara terpisah dari aktivitas belajar. Pembelajaran daring diselenggarakan melalui jejaring internet dan web 2.0 (Alessandro, 2018), artinya bahwa penggunaan pembelajaran daring melibatkan unsur teknologi sebagai sarana dan jaringan internet sebagai sistem. Pembelajaran daring telah banyak dilakukan dalam konteks perguruan tinggi, terbukti dari beberapa penelitian yang menjelaskan hal tersebut (Crews, J., \& Parker, 2017; Mather \& Sarkans, 2018), pembelajaran daring memberikan manfaat dalam membantu menyediakan akses belajar bagi semua orang, sehingga menghapus hambatan secara fisik sebagai faktor untuk belajar dalam ruang lingkup kelas (Riaz, 2018), bahkan hal tersebut dipandang sebagai sesuatu yang efektif untuk diterapkan khususnya dalam perguruan tinggi, akan tetapi tidak bisa dipungkiri bahwa tidak semua pembelajaran dapat dipindahkan ke dalam lingkungan pembelajaran secara online (Pilkington, 2018).

Pembelajaran daring memungkinkan mahasiswa memiliki keleluasaan waktu belajar sehingga dapat belajar kapanpun dan dimanapun. Selain itu, mahasiswa dapat berinteraksi dengan dosen menggunakan beberapa aplikasi seperti e-classroom, video conference, telepon atau live chat, zoom maupun melalui whatsapp group (Dhull, 2017). Kegiatan pembelajaran tersebut merupakan sebuah inovasi pendidikan untuk menjawab tantangan akan ketersediaan sumber belajar yang variatif. Keberhasilan dari suatu model ataupun media pembelajaran tergantung dari karakteristik peserta didiknya. Hal ini diungkapkan oleh bahwa dari semua literatur mengindikasikan bahwa tidak semua peserta didik akan sukses dalam pembelajaran online, hal itu disebabkan karena perbedaan faktor lingkungan belajar dan karakteristik peserta didik (Astini, Sari, 2020). Salah satu keberhasilan dalam pembelajaran adalah terkait dengan motivasi yang dimiliki siswa (Alhabeeb \& Rowley, 2018). Motivasi adalah sebuah konstruksi teoretis untuk menjelaskan inisiasi, arah, intensitas, ketekunan, dan kualitas perilaku, terutama perilaku yang diarahkan pada tujuan. Motivasi memberikan dorongan untuk tindakan yang bertujuan dengan arah yang diinginkan Baik fisik maupun mental, sehingga aktivitas menjadi bagian yang sangat penting dalam motivasi (Lee \& Martin, 2017). Motivasi dapat memengaruhi apa yang kita pelajari, bagaimana kita belajar, dan kapan kita memilih untuk belajar (Alhabeeb \& Rowley, 2018). Hal ini juga ditunjukan dari penelitian yang menjelaskan bahwa peserta didik yang termotivasi lebih cenderung melakukan kegiatan yang menantang, terlibat aktif, menikmati proses kegiatan untuk belajar dan menunjukkan peningkatan hasil belajar, ketekunan dan kreativitas (Dewi et al., 2020), selain itu, merancang lingkungan belajar yang memotivasi siswa akan menarik perhatian peserta didik (Anastasiadis et al., 2018).

Pembelajaran daring sering dituntut untuk lebih termotivasi karena lingkungan belajar biasanya bergantung pada motivasi dan karakteristik terkait dari rasa ingin tahu dan pengaturan diri untuk melibatkan pada proses pembelajaran (Fitriyani et al., 2020). Motivasi adalah bagian yang kompleks dari orang-orang, yang dapat mempengaruhi jumlah energi yang mereka keluarkan untuk melakukan sesuatu. Lebih lanjut dijelaskan bahwa motivasi akan mempengaruhi usaha, ketekunan dan pengaruh seseorang dalam menentukan solusi atas hambatan yang dihadapi seseorang dalam memecahkan masalah. Dimana motivasi merupakan alasan dibalik perilaku seseorang. Tidak hanya itu, motivasi adalah kualitas yang mendorong orang untuk melakukan dan tidak melakukan sesuatu. Berdasarkan hal tersebut, sangat penting bagi seorang guru untuk membangkitkan motivasi belajar siswa. Sehingga dalam pembelajaran guru harus terlibat aktif dalam memotivasi belajar siswa dengan kegiatan pembelajaran yang dilakukan (Siswati et al., 2017). Faktanya, teknologi itu sendiri dipandang oleh sebagian orang sebagai motivasi yang inheren karena memberikan sejumlah kualitas yang diakui penting dalam menumbuhkan motivasi intrinsik, yaitu tantangan, keingintahuan, kebaruan dan fantasi (Arnellis et al., 2021; Reyneke et al., 2020), motivasi dianggap sebagai faktor penting untuk keberhasilan belajar termasuk dalam lingkungan belajar daring, sehingga perlunya mempertimbangkan kembali motivasi belajar di lingkungan belajar yang memanfaatkan teknologi (Fitriyani et al., 2020), dengan alasan tersebut maka penting bagi para peneliti 
dalam dunia pendidikan untuk mengkaji secara mendalam tentang bagaimana motivasi mahasiswa pada pembelajaran daring terlebih kegiatan pembelajarannya dilakukan selama masa Pandemik Covid-19.

Dalam motivasi yang diidentifikasi terdiri dari penilaian dan emosi yang terjadi secara bersamaan pada awal dua semester e-learning, di mana siswa dengan kesenangan pengendalian yang tinggi melaporkan keberhasilan yang lebih baik dan nilai yang diharapkan lebih baik dari pada siswa sedikit kebosanan. Kontrol kebosanan yang rendah terlihat pada semua tes (Parker et al., 2021). Motivasi belajar dianggap penting karena dengan motivasi belajar siswa dapat terlibat aktif dalam pembelajaran. Penting juga untuk menentukan seberapa banyak siswa akan belajar dari aktivitas yang mereka lakukan di kelas selama proses pembelajaran (Vanslambrouck et al., 2018). Pada siswa yang termotivasi dalam proses pembelajaran lebih memanfaatkan keterampilan kognitifnya dan ini mempengaruhi pemahaman belajar sesuatu, selain proses kognitif siswa juga mempengaruhi kreativitas siswa (Siswati et al., 2017). Hasil pembelajaran siswa terlihat meningkat secara signifikan dari sebelumnya dengan meningkatkan motivasi siswa tersebut (Suyanti et al., 2021). Peningkatan motivasi belajar siswa selama pembelajaran online menunjukkan adanya pengaruh terhadap hasil belajar siswa. Disinilah siswa paling aktif dalam proses pembelajaran, terbukti dengan hasil belajar yang mengalami perubahan positif dan meningkat (Agustina et al., 2021).

Jabaran tersebut menjadi sebuah alasan mengapa penelitian ini dilakukan, mengangat pentingnya motivasi belajar dalam proses pembelajaran daring. Penelitian sebelumnya sudah membahas tentang motivasi pembelajaran pada anak uasia dini serta siswa sekolah dasar, penelitian ini berbeda dengan penelitian yang sudah ada, yang mana penelitian ini dilkukan di tingat mahasiswa dengan aspek yang diteliti dalam penelitian ini terkait dengan aspek yang dijelaskan sebelumnya, yang mana menuliskan 8 indikator motivasi belajar, yaitu konsentrasi, rasa ingin tahu, semangat, kemandirian, kesiapan, antusias atau dorongan, pantang menyerah, dan percaya diri. Penelitian ini dilakukan dengan tujuan memberikan gambaran secara objektif bagaimana motivasi belajar mahasiswa pada pembelajaran daring selama masa Pandemik Covid-19, sehingga hal ini menjadi bahan evaluasi dalam menciptakan pembelajaran daring yang efektif ditengah Pandemik covid-19, selain itu penelitian ini juga dapat menjadi bahan kajian peneliti lain terkait motivasi mahasiswa pada pembelajaran daring selama masa Pandemik Covid-19.

\section{METODE}

Penelitian ini menggunakan penelitian kuantitatif. Penelitian kuantitatif berupaya untuk mengungkap kebenaran dan prinsip universal dalam bentuk hubungan antar variabel atau fenomena (Fitriyani et al., 2020). Ciri dalam penelitian kuantitatif yaitu teknik analisis datanya menggunakan teknik kuantitatif (statistika) secara objektifc. Sedangkan jenis penelitian ini menggunakan metode survey. Penelitian survey dipandang sebagai metode untuk menggambarkan secara kuantitatif aspek-aspek spesifik dari populasi tertentu sehingga pengumpulan datanya dilakukan kepada sekolompok orang yang hasilnya dapat digeneralisasi kembali ke dalam suatu populasi tertentu (Kivinen et al., 2021). Penelitian survey sangat cocok digunakan dalam mengungkap bagaimana motivasi mahasiswa dalam pembelajaran daring pada masa Pandemik Covid-19 ini. Subjek dalam penelitian ini adalah mahasiswa aktif di PSDKU Universitas Triatma Mulya, Jembrana yang berjumlah 50 orang yang mendapatkan pembelajaran daring selama masa Pandemik Covid-19. Instrumen yang digunakan dalam penelitian ini menggunakan data survey. Adapun surveynya dalam bentuk kuisioner yang dibuat dalam google form agar mudah diakses oleh mahasiswa. Survey yang dibuat bertujuan untuk mengungkap secara detail tentang motivasi mahasiswa dalam pembelajaran daring selama masa Pandemik Covid-19, adapun jenis surveynya menggunakan skala likert. Skala likert digunakan sebagai alat untuk mengukur sikap, pendapat, dan persepsi individu atau sekolompok orang terhadap fenomena social (Sugiyono, 2018). Sementara itu, teknik analisis data pada penelitian ini dilakukan dengan menghitung presentase dari hasil skor yang telah diperoleh.

\section{HASIL DAN PEMBAHASAN}

Hasil

Survey motivasi belajar diberikan kepada 50 mahasiswa program studi pendidikan guru sekolah dasar di Universitas Triatma Mulya, dengan rincian 12 mahasiswa laki-laki dan 38 mahasiswa perempuan. Adapun hasil survey ditunjukan pada Tabel 1. 
Tabel 1. Hasil Survey Mahasiswa terhadap motivasi belajar

\begin{tabular}{|c|c|c|c|}
\hline Indikator & & persentase & kriteria \\
\hline \multirow[t]{11}{*}{ Konsentrasi } & Perhatian terhadap penyampain kompetensi & $70,75 \%$ & Baik \\
\hline & Memahami intruksi yang diberikan dosen & $78,25 \%$ & Baik \\
\hline & Konsentrasi terhadap bahan dan materi ajar & $73,75 \%$ & Baik \\
\hline & Perhatian terhadap penyampain kompetensi & $76,5 \%$ & Baik \\
\hline & Memahami intruksi yang diberikan dosen & $73,75 \%$ & Baik \\
\hline & Konsentrasi terhadap bahan dan materi ajar & $73,5 \%$ & Baik \\
\hline & Mendengarkan dengan baik setiap penjelasan materi & & Sangat \\
\hline & yang disampaikan & $84 \%$ & Baik \\
\hline & Memperhatikan penyampaian dan penjelasan dosen & $75 \%$ & Baik \\
\hline & $\begin{array}{l}\text { Mencatat materi yang disampaikan pada saat } \\
\text { pembelajaran }\end{array}$ & $78,5 \%$ & Baik \\
\hline & $\begin{array}{l}\text { Mematuhi peraturan yang diberikan pada saat } \\
\text { pembelajaran berlangsung }\end{array}$ & $73,25 \%$ & Baik \\
\hline \multirow[t]{2}{*}{$\begin{array}{l}\text { Rasa Ingin } \\
\text { tahu }\end{array}$} & $\begin{array}{l}\text { Ketertarikan terhadap bahan dan materi yang } \\
\text { disampaikan }\end{array}$ & $70,75 \%$ & Baik \\
\hline & $\begin{array}{l}\text { Mengajukan pertanyaan terhadap materi yang } \\
\text { diajarkan }\end{array}$ & $75,25 \%$ & Baik \\
\hline Semangat & $\begin{array}{l}\text { Semangat dalam menyampaikan ide dan pendapat } \\
\text { pada saat pembelajar }\end{array}$ & $70 \%$ & Baik \\
\hline Kemandirian & $\begin{array}{l}\text { Mampu menjawab atau mengerjakan dengan baik } \\
\text { tugas-tugas yang diberikan }\end{array}$ & $79,25 \%$ & Baik \\
\hline Kesiapan & $\begin{array}{l}\text { Antusias dan siap dalam menjawab atau mengerjakan } \\
\text { tugas-tugas yang diberikan }\end{array}$ & $79,75 \%$ & baik \\
\hline $\begin{array}{l}\text { Antusias atau } \\
\text { Dorongan }\end{array}$ & $\begin{array}{l}\text { Mempunyai keinginan untuk mendapatkan nilai } \\
\text { terbaik dari setiap tugas }\end{array}$ & $79,75 \%$ & baik \\
\hline $\begin{array}{l}\text { Pantang } \\
\text { Menyerah }\end{array}$ & Bersungguh-sungguh dalam dalam mengerjakan tugas & $75,75 \%$ & Baik \\
\hline \multirow[t]{3}{*}{ Percaya Diri } & Percaya diri dalam mengerjakan tugas & $76,75 \%$ & Baik \\
\hline & Percaya diri dengan skor yang akan saya dapatkan & $74,75 \%$ & Baik \\
\hline & Rata-rata & $76.33 \%$ & Baik \\
\hline
\end{tabular}

Dari Tabel 1 menunjukkan bahwa beberapa aspek yang diperhatikan dalam melihat konsentrasi mahasiswa diantaranya adalah 1) perhatian terhadap penyampain kompetensi dengan skor persentase 70,75\% termasuk kriteria baik, di awal pembelajaran biasanya disampaikan kompetensi yang akan dicapai, hal ini sangat penting untuk menjadi acuan dalam kegiatan pembelajaran, skor presentase tersebut menunjukkan bahwa mahasiswa memperhatikan kompetensi dari setiap mata kuliah yang akan diajarkan, 2) memahami intruksi yang diberikan dosen dengan skor persentase 78,25\% termasuk kriteria baik, 3) konsentrasi terhadap bahan dan materi ajar dengan skor persentase $73,75 \%$ termasuk kriteria baik sehingga dapat diartikan bahwa mahasiswa memiliki kemampuan konsentrasi dan fokus yang baik terhadap materi ajar pada kegiatan pembelajaran. Kemampuan dosen dalam menyiapkan bahan dan materi ajar akan membantu mahasiswa dalam memahami materi yang akan disampaikan, 4) mendengarkan dengan baik setiap penjelasan materi yang disampaikan dengan skor persentase $84 \%$ termasuk kriteria sangat baik, ini menunjukkan bahwa proses kegiatan pembelajaran secara online dapat berjalan dengan optimal, 5) memperhatikan penyampaian dan penjelasan dengan skor persentase $75 \%$ termasuk kriteria baik, 6) mencatat materi yang disampaikan pada saat pembelajaran dengan skor persentase 78,5\% termasuk baik, kegiatan mencatat poin penting dari setiap materi yang disampaikan akan membantu mahasiswa dalam mencapai hasil belajar yang baik, dan 7) mematuhi peraturan yang diberikan pada saat pembelajaran berlangsung dengan skor persentase 73,5\% termasuk kriteria baik sehingga dapat diartikan bahwa mahasiswa mampu memahami dan menjalankan setiap peraturan perkuliahan yang telah disepakati bersama. Sehingga dari hal-hal tersebut dapat ditarik simpulan motivasi belajar mahasiswa berada pada katagori baik.

Motivasi belajar siswa dapat muncul dikarenakan adanya faktor-faktor yang mempengaruhinya, mulai dari faktor eksternal dan juga faktor internal. Faktor internal adalah faktor yang muncul dari dalam diri sendiri seperti faktor fisik maupun psikis. Motivasi eksternal ialah motivasi yang muncul luar diri 
seperti kerapat, keluarga dan juga guru, faktor ini juga telah terbukti mampu memenuhi kebutuhan psikologis masyarakat dan berkorelasi positif dengan prestasi akademik siswa. Perilaku dan keterampilan peserta didik yang berasal dari dalam diri merupakan faktor penentu keberhasilan belajar dan dapat juga dibantu oleh faktor eksternal atau dorongan eksternal untuk meningkatkan motivasi belajar dengan mengubah gaya belajar menjadi lebih nyaman untuk dilakukan (Fath \& Sugito, 2021). Dengan diberikannya motivasi belajar maka siswa yang memiliki motivasi intrinsik tersebut mampu untuk belajar dengan hasil belajar yang lebih tinggi dalam kondisi apapun dibandingkan dengan siswa yang tidak diberikan motivasi belajar (Purwanto, 2016).

Motivasi belajar juga menghasilkan dosen dan mahasiswa mempunyai hubungan pedagogis yang saling timbal balik, yang mampu meningkatkan konsentrasi mahasiswa, sehingga aplikasi yang mendukung proses belajar, dan pemanfaatan media dan bahan ajar yang interaktif mampu di gunakan dengan maksimal. Indikator yang terkait dengan motivasi belajar ialah rasa ingin tahu mahasiswa. Rasa ingin tahu ini merupakan modal awal yang sangat penting dalam proses pembelajaran, dengan keingintahuan yang tinggi maka keinginanan akan mendorong siswa dalam menemukan apa ingin diketahuinya (Fauzi, A. R. \& Atok, 2017). Adapun aspek rasa ingin tahu yang diteliti ialah 1) ketertarikan terhadap bahan dan materi yang disampaikan dan 2) mengajukan pertanyaan terhadap materi yang diajarkan sehingga dengan demikian dapat diartikan bahwa mahasiswa mampu memiliki keberanian dalam mengajukan pertanyaan sehingga tercipta pembelajaran yang aktif dan tercipta pembelajaran dua arah tidak hanya satu arah. Motivasi lainnya berkaitan dengan semangat dalam belajar, motivasi dan semangat belajar mempunyai hubungan yang sangat penting pada kegiatan pembelajaran, ini menunjukkan bahwa baik dosen dan mahasiswa harus menunjukkan semangat yang tinggi pada setiap kegiatan pembelajaran, semangat pendidik dalam mengajar siswa berhubungan erat dengan minat siswa yang belajar. Aspek yang terkait berkaitan dengan semangat dalam menyampaikan ide dan pendapat pada saat pembelajaran sehingga dapat diartikan bahwa mahasiswa berani dalam menyampaikan pendapat ide dan pendapat meskipun melalui pembelajaran daring.

Motivasi juga menghasilkan kemandirian, dimana kemandirian dalam belajar menjadi hal yang juga penting dalam menggali setiap aspek yang akan dipelajari, Beberapa penelitian telah menjelaskan bahwa ada hubungan yang signifikan antara kemandirian belajar dengan hasil belajar baik dalam pembelajarn langsung maupun dalam pembelajaran jarak jauh (Nurhayati, 2019). Efek dari motivasi lainnya berupa kesiapan mahasiswa, yang mana antusias dan siap dalam mahasiswa dalam menjawab. Kondisi pembelajaran daring pada masa Pandemik Covid-19 memiliki cukup keterbatasan, hal inilah yang menjadikan beberapa dosen sering memberikan tugas mata kuliah, bahkan mahasiswa menganggap bahwa tugas yang diberikan pada masa Pandemik Covid-19 jauh lebih banyak dibandingkan dengan perkliahan normal secara tatap muka dan menuntut mahasiswa lebih antusias dan siap dalam mengerjakannya. Pantang menyerah juga menjadi efek motivitasi yang dihasilkan serta kunci utama setiap mahasiswa untuk mendapatkan hasil terbaik. Hal lain yang menjadi efek dari motivasi adalah percaya diri, dari hal tersebut mahasiswa mampu percaya diri dalam mengerjakan tugas.

Berdasarkan hasil analisis motivasi mahasiswa terhadap pembelajaran daring selama masa pandemik covid-19 yang diperoleh rata-rata skor presentase keseluruhan adalah 76,33\% dengan kategori baik, sehingga dapat diartikan bahwa mahasiswa PSDKU Universitas Triatma Mulya memiliki motivasi yang tinggi terhadap pembelajaran daring selama masa pandemik Covid-19. Masa pandemik covid-19 tidak menghalangi motivasi mahasiswa dalam melakukan kegiatan pembelajaran secara daring. Di tengah kedaruratan yang melanda dunia, tidak ada pilihan lain selain menerapkan konsep pembelajaran secara daring, ada beberapa catatan yang harus diperhatikan agar pembelajaran daring tetap optimal yaitu berkaitan dengan kesiapan belajar diantaranya adalah kepercayaan diri terhadap penggunaan computer/internet, pembelajaran secara mandiri, pengendalian pelajar/mahasiswa, motivasi untuk belajar, dan kepercayaan diri terhadap komunikasi secara online (Sepita \& Suryanti, 2020).

\section{SIMPULAN}

Simpulan dalam penelitian ini adalah bahwa dari indikator-indikator motivasi belajar yaitu konsentrasi, rasa ingin tahu, semangat, kemandirian, kesiapan, antusias atau dorongan, pantang menyerah, dan percaya diri menunjukkan kriteria baik, hal ini dapat dikatakan bahwa ditengah pandemic covid-19 yang melanda dunia, hal tersebut tidak menjadi alasan mahasiswa untuk tidak memiliki motivasi belajar yang tinggi, walaupun dalam pelaksanaannya terdapat kekurang-kekurangan yang ditemukan, akan tetapi tidak ada pilihan lain selain mengoptimalkan pembelajaran daring, karena dalam kondisi darurat seperti ini, hanya teknologilah yang menjadi jembatan dalam mentransfer pengetahuan dari dosen ke mahasiswa. 


\section{DAFTAR PUSTAKA}

Agustina, M., Azizah, E. N., \& Koesmadi, D. P. (2021). Pengaruh Pemberian Reward Animasi terhadap Motivasi Belajar Anak Usia Dini selama Pembelajaran Daring. Jurnal Obsesi : Jurnal Pendidikan Anak Usia Dini, 6(1), 353-361. https://doi.org/10.31004/obsesi.v6i1.1331.

Alessandro, B. (2018). Digital Skills and Competence, and Digital and Online Learning. Turin: European Training Foundation. 10/DSC\%20and\%20DOL_0.pdf.

Alhabeeb, A., \& Rowley, J. (2018). E-learning critical success factors: Comparing perspectives from academic staff and students. Computers and Education, 127(August), 1-12. https://doi.org/10.1016/j.compedu.2018.08.007.

Almeida, F., \& Simoes, J. (2019). The Role of Serious Games, Gamification and Industry 4.0 Tools in the Education 4.0 Paradigm. Contemporary Educational Technology, 10(2), 120-136. https://doi.org/https://doi.org/10.30935/cet.554469.

Anastasiadis, T., Lampropoulos, G., \& Siakas, K. (2018). Digital Game-based Learning and Serious Games in Education. International Journal of Advances in Scientific Research and Engineering, 4(12), 139144. https://doi.org/10.31695/ijasre.2018.33016.

Arnellis, Jamaan, E. Z., Amalita, N., Rosha, M., \& Fitria, D. (2021). The Impact of Application on Calculus 1 Teaching Materials by Using Google Classroom Media to Increase Students' Motivation. Journal of Physics: Conference Series, 1940(1), 012106. https://doi.org/10.1088/17426596/1940/1/012106.

Astini, Sari, N. K. (2020). Pemanfaatan Teknologi Informasi dalam Pembelajaran Tingkat Sekolah Dasar pada Masa Pandemi Covid-19. Jurnal Lembaga Penjaminan Mutu STKIP Agama Hindu Amlapura, 11(2), 13-25. https://doi.org/10.47730/jurnallampuhyang.v11i2.194.

Aziz Hussin, A. (2018). Education 4.0 Made Simple: Ideas For Teaching. International Journal of Education and Literacy Studies, 6(3), 92-98. https://doi.org/10.7575/aiac.ijels.v.6n.3p.92.

Crews, J., \& Parker, J. (2017). The Cambodian Experience: Exploring University Students'. https://www.iier.org.au/iier27/crews.pdf.

Dewi, N. R., Saputri, E., Nurkhalisa, S., \& Akhlis, I. (2020). The effectiveness of multicultural education through traditional games-based inquiry toward improving student scientific attitude. Journal of Physics: Conference Series, 1567(4). https://doi.org/10.1088/1742-6596/1567/4/042051.

Dhull, I. dan S. (2017). Online Learning. International Education \& Research Journal (IERJ), 3(8), 32-34. https://www.researchgate.net/publication/332833360_Online_Learning.

Erwinsyah, A. (2017). Manajemen kelas dalam meningkatkan efektifitas proses belajar mengajar. TADBIR: Jurnal Manajemen Pendidikan Islam, 5, 88-105. https://journal.iaingorontalo.ac.id/index.php/tjmpi/article/view/392.

Fath, A. M. AL, \& Sugito. (2021). Meningkatkan Motivasi Belajar Siswa Kelas IV Melalui Media Video. $\begin{array}{llr}\text { Elementary School, 8(2), 58-66. } & \text { 8 }\end{array}$ http://www.tjyybjb.ac.cn/CN/article/downloadArticleFile.do?attachType=PDF\&id=9987.

Fauzi, A. R., Z., \& Atok, R. Al. (2017). Penguatan Karakter Rasa Ingin Tahu dan Peduli Sosial melalui Discovery Learning. Jurnal Teori Dan Praksis Pembelajaran IPS, 2(2).

Fitriyani, Y., Fauzi, I., \& Sari, M. Z. (2020). Motivasi Belajar Mahasiswa Pada Pembelajaran Daring Selama Pandemik Covid-19. Profesi Pendidikan Dasar, 7(1), 121-132. https://doi.org/10.23917/ppd.v7i1.10973.

Fomunyam, K. G. (2019). Education and the Fourth Industrial Revolution : Challenges and Possibilities for Engineering. International Journal of Mechanical Engineering and Technology (IJMET), 10(8), 271$284 . \quad$ https://www.academia.edu/40258817/ Education _and_the_Fourth_Industrial_Revolution_Challenges_And_Possibilities_For_Engineering_Education.

Gamar, M. M., Al Faruq, M. S., \& Lina, L. (2018). Challenging the Indonesian Primary Education in Industrial Revolution 4.0 Era. 3rd International Conference on Education Management and Administration (CoEMA 2018), 269, 46-48. https://doi.org/10.2991/coema-18.2018.12.

Husaini, M. (2019). Pemanfaatan Teknologi Informasi Dalam Bidang Pendidikan (E-education). JURNAL MIKROTIK, 2(1). https://doi.org/10.31219/osf.io/ycfa2.

Kivinen, J., Smola, A. J., \& Williamson, R. C. (2021). Analysis the Influence of Online Learning on Students' Learning Enthusiasm. 6(1), 1-11. https://www.learntechlib.org/p/219899/.

Lee, J., \& Martin, L. (2017). Investigating Students' Perceptions of Motivating Factors of Online Class Discussions. International Review of Research in Open and Distance Learning, 18(5), 148-172. 
https: //doi.org/10.19173/irrodl.v18i5.2883.

Mather, M., \& Sarkans, A. (2018). Student Perceptions of Online and Face-to-Face Learning. International Journal of Curriculum and Instruction, 10(2), 61-76. https://core.ac.uk/download/pdf/268081682.pdf.

Mustofa, M. I., Chodzirin, M., Sayekti, L., \& Fauzan, R. (2019). Formulasi Model Perkuliahan Daring sebagai Upaya Menekan Disparitas Kualitas Perguruan Tinggi. Walisongo Journal of Information Technology, 1(2), 151. https://doi.org/10.21580/wjit.2019.1.2.4067.

Nurhayati, E. (2019). Penerapan Buku Saku dengan Pendekatan Saintifik untuk Meningkatkan Motivasi dan Hasil Belajar Siswa Pasca Gempa Bumi. Jurnal Kependidikan: Jurnal Hasil Penelitian Dan Kajian Kepustakaan Di Bidang Pendidikan, Pengajaran Dan Pembelajaran, 5(2), 94-99. https: //doi.org/10.33394/jk.v5i2.1804.

Orgaz, F., Moral, S., \& Domínguez, C. (2018). Student's Attitude and Perception with the Use of Technology in the University. Journal of Educational Psychology - Propositos Y Representaciones, 6(2), 277299. https://doi.org/http://dx.doi.org/10.20511/.

Parker, P. C., Perry, R. P., Hamm, J. M., Chipperfield, J. G., Pekrun, R., Dryden, R. P., Daniels, L. M., \& Tze, V. M. C. (2021). A motivation perspective on achievement appraisals, emotions, and performance in an online learning environment. International Journal of Educational Research, 108(March), 101772. https://doi.org/10.1016/j.ijer.2021.101772.

Pilkington, O. A. (2018). Active Learning for an Online Composition Classroom: Blogging as an Enhancement of Online Curriculum. Journal of Educational Technology Systems, 47(2), 1-14. https://doi.org/10.1177/0047239518788278.

Purwanto. (2016). Pengaruh Konsekuensi Perilaku dan Motivasi Belajar Terhadap Hasil Belajar. Jurnal Pendidikan Dan Kebudayaan. https://doi.org/10.24832/jpnk.v13i69.347.

Reyneke, J. A., Davis, K., Ed, D., \& Chairperson, D. (2020). Graduate School of Education and Psychology What Drives Educators: a Mixed Methods Study on the Impact of Motivasions and Attitudes on Technology Integration Practices in the k-8 Classroom Setting a dissertation submitted in partial satisfaction of the r. https://media.proquest.com/media/hms/PFT/2/dpW9H?_s=6 uXrF5QyJpxfaXw6sBDaaXw33XA\%3D.

Riaz, A. (2018). Effects of Online Education on Encoding and Decoding Process of Students and Teachers. International Conference E-Learning, 42-48. https://doi.org/https: //files.eric.ed.gov/fulltext/ED590288.pdf.

Sarıçoban, A., Tosuncuoğlu, I., \& Kırmizi, Ö. (2019). A Technological Pedagogical Content Knowledge (TPACK) Assessment of Preservice EFL Teachers Learning to Teach English as a Foreign Language. Journal of Language and Linguistic Studies, 15(3), 1122-1138. https://doi.org/10.17263/jlls.631552.

Sepita, S. F., \& Suryanti, S. (2020). Pengaruh Pembelajaran Daring Terhadap Hasil Belajar Kognitif Mahasiswa Pada Mata Kuliah Limnologi. Journal of Research and Education Chemistry, 2(2), 102. https: //doi.org/10.25299/jrec.2020.vol2(2).5826.

Siswati, B. H., Hariyadi, S., \& Corebima, A. D. (2017). Pengaruh Model Pembelajaran RQAAD Terhadap Motivasi Belajar dan Keterampilan Metakognitif Mahasiswa Mata Kuliah Strategi Belajar Mengajar Biologi. Jurnal Pendidikan Biologi, $7(2), \quad 108-116$. http://jurnal.unimed.ac.id/2012/index.php/JPB.

Sugiyono. (2018). Metode Penelitian Kuantitatif, Kualitatif dan R\&D. CV Alfabeta.

Suyanti, S., Sari, M. K., \& Rulviana, V. (2021). Media Powtoon Untuk Meningkatkan Motivasi Belajar Siswa Sekolah Dasar. Elementary School: Jurnal Pendidikan Dan Pembelajaran Ke-SD-An, 8(2), 322-328. https: //doi.org/10.31316/esjurnal.v8i2.1468.

Tinmaz, H., \& Lee, J. H. (2019). A Preliminary Analysis on Korean University Students' Readiness Level for Industry 4.0 Revolution. Participatory Educational Research (PER), 6(1), 70-83. https://doi.org/http://dx.doi.org/10.17275/per.19.6.6.1.

Traxler, J. (2018). Distance learning-Predictions and possibilities. Education Sciences, 8(1), 1-13. hhttps://doi.org/10.3390/educsci8010035.

Vanslambrouck, S., Zhu, C., Lombaerts, K., Philipsen, B., \& Tondeur, J. (2018). Students' motivation and subjective task value of participating in online and blended learning environments. Internet and Higher Education, 36, 33-40. https://doi.org/10.1016/j.iheduc.2017.09.002.

Yin, Y., \& Qin, S.-F. (2019). A Smart Performance Measurement Approach for Collaborative Design in Industry 4.0. Advances in Mechanical Engineering, 11(1), 1-15. https://doi.org/10.1177/1687814018822570. 